\title{
ANALISIS KOEFISIEN GESEK KINETIS BENDA DI BIDANG MIRING MENGGUNAKAN VIDEO TRACKER
}

\author{
Florentina Andriani ${ }^{1}$, Selvistika Suryanti Busri ${ }^{1}$, Wilhelmina Rande ${ }^{1}$, \\ Yohana Melci Joni ${ }^{1}$, Richardo Barry Astro ${ }^{2}$ \\ ${ }^{1}$ Mahasiswa Pendidikan Fisika, FKIP, Universitas Flores \\ ${ }^{2}$ Program Studi Pendidikan Fisika, FKIP, Universitas Flores \\ e-mail: florentinaandriani1998@gmail.com
}

\begin{abstract}
ABSTRAK
Penelitian ini bertujuan untuk menentukan nilai koefisien gesek kinetis pada dua buah balok kayu, dengan panjang $\mathrm{m}_{1}=8 \mathrm{~cm}$, lebar $=4 \mathrm{~cm}$, dan tingginya $=5 \mathrm{~cm}$ dan $\mathrm{m}_{2}:$ panjang $=5$ $\mathrm{cm}$, lebar $=4 \mathrm{~cm}$ dan tingginya $=3 \mathrm{~cm}$ terhadap landasan kayu. Metode yang digunakan dalam penelitian ini adalah metode eksperimen. Eksperimen ini dilaksanakan pada April 2020 bertempat di rumah peneliti, jalan Sam Ratulangi Ende. Permukaan dan panjang bidang miring dibuat konstan, dengan sudut kemiringan bidang yang dapat diatur. Variabel terikat dalam penelitian ini adalah koefisien gesek kinetis dan variabel bebasnya adalah video tracker Eksperimen menggunakan variasi sudut kemiringan $26^{\circ}, 28^{\circ}$, dan $30^{\circ}$. Penentuan nilai koefisien gesek kinetis dilakukan dengan cara mengamati luncuran benda dari puncak bidang miring yang didokumentasikan dalam bentuk video. Selanjutnya video dianalisis menggunakan aplikasi Tracker. Tracker merupakan aplikasi yang mampu melakukan pelacakkan pada gerak suatu objek sehingga dapat diperoleh informasi yang dibutuhkan dalam analisis pada suatu peristiwa gerak. Data hasil analysis video ditampilkan dalam bentuk grafik kecepatan terhadap waktu. Metode tracking terbukti memberikan hasil pengukuran yang konsisten sehingga dapat dintegrasikan dalam penentuan koefisien gesek kinetisdan eksperimen kinematika lainnya. Koefisien gesek kinetis antara balok kayu terhadaplandasan papan kayu pada eksperimen ini diperoleh nilai pada balok $\mathrm{m}_{1}$ sebesar 0,3341 dan balok $\mathrm{m}_{2}$ sebesar 0,3561 .
\end{abstract}

Kata-kata kunci: koefisiengesek kinetis, bidang miring, video tracker

\section{ABSTRACT}

This study aims to determine the value of the coefficient of kinetic friction on two wooden blocks, with length $m 1=8 \mathrm{~cm}$, width $=4 \mathrm{~cm}$, and height $=5 \mathrm{~cm}$ and $m 2:$ length $=5 \mathrm{~cm}$, width $=4 \mathrm{~cm}$ and height $=3 \mathrm{~cm}$ to the wooden base. The method used in this research is the experimental method. This experiment was carried out in April 2020 at the researcher's house, Jalan Sam Ratulangi Ende. The surface and length of the inclined plane are kept constant, with the angle of inclination of the plane adjustable. The dependent variable in this study is the coefficient of kinetic friction and the independent variable is the video tracker. Experiments using variations in tilt angles of $26^{\circ}, 28^{\circ}$, and 30. Determination of the value of the coefficient of kinetic friction is done by observing the slide of the object from the top of the inclined plane which is documented in the form of video. Furthermore, the video is analyzed using the Tracker application. Tracker is an application that is able to track the motion of an object so that the information needed in the analysis of a motion event can be obtained. The data from the video analysis is displayed in the form of a graph of speed against time. The tracking method is proven to provide consistent measurement results so that it can be integrated in determining the coefficient of kinetic friction and other kinematics 
experiments. The coefficient of kinetic friction between the wooden block and the wooden plank base in this experiment is obtained by the value of the $m_{1}$ beam of 0.3341 and the $m_{2}$ beam of 0.3561 .

Keywords: kinetic friction coefficient, inclinedplane, video tracker

\section{PENDAHULUAN}

Fisika merupakan salah satu dasar dari ilmu rekayasa dan teknologi yang dapat mempengaruhi cara berpikir dalam menyelesaikan persoalan yang berkaitan dengan fenomena-fenomena alam. Hal terpenting yang harus diperhatikan dalam melakukan eksperimen fisika adalah set eksperimen yang digunakan. Set eksperimen sangat menentukan hasil yang didapatkan pada suatu penelitian salah satunya adalah set eksperimen di bidang miring untuk menentukan kofisien gesek kinetis (Winingsih \& Hidayati, 2017). Salah satu yang sering ditemui dalam kehidupan sehari-hari adalah fenomena gesekan. Gaya gesek merupakan salah satu topik yang menarik untuk dikaji dalam pembelajaran fisika (Humairo et al., 2015). Gaya gesek timbul akibat gerakan relatif antar dua permukaan yang bersinggungan sehingga gerakan yang satu terhadap gerakan yang lain menjadi tidak leluasa dan mengalami hambatan. Semakin besar gaya geseknya maka semakin lekat atau kuat persinggungan tersebut (Setyarini \& Natalisanto, 2016).

Gaya gesek terjadi apabila dua benda saling melakukan kontak atau saling bersentuhan, dan memiliki arah berlawanan dengan gerak benda atau lebih cenderung kearah benda akan bergerak (Hernawati, 2013). Gaya gesek dipengaruhi oleh tingkat kekasaran pemukaan kedua benda yang bersentuhan dan juga gaya kontak antara dua benda (gaya normal) (Fuadi, 2016). Kekasaran permukaan akan mempengaruhi koefisien gesek pada bidang kontak(Fitrianto et al., 2015).

Gaya gesek yang bekerja saat sebuah benda bergerak terhadap medium lain disebut gaya gesek kinetis. Salah satu cara mempelajari gaya gesek adalah dengan meluncurkan sebuah benda pada sistem bidang miring (Kurniawan \& Handayani, 2018). Sebuah benda yang diletakkan pada bidang miring akan meluncur selama komponen gaya besar pada arah sejajar bidang miring lebih besar dari gaya gesek statis maksimum. Saat benda bergerak meluncur, gaya gesek yang bekerja adalah gaya gesek kinetis. Diagram gaya pada sebuah benda yang diletakkan pada bidang miring ditunjukkan pada Gambar 1.

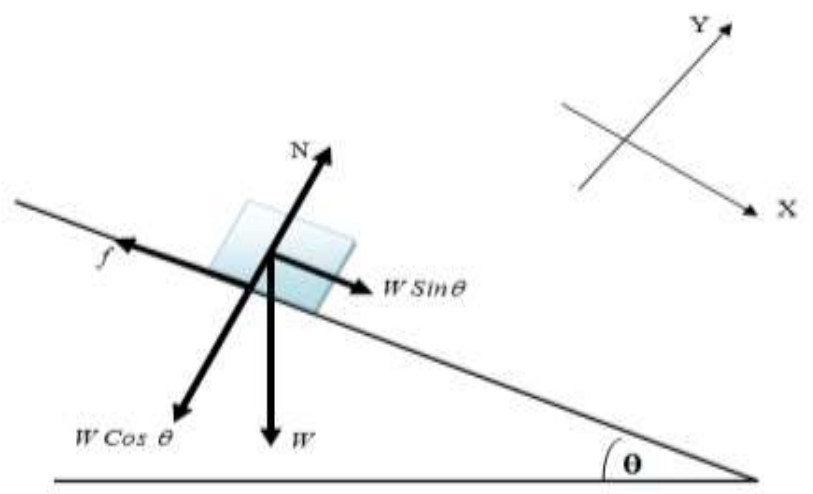

Gambar 1. Diagram gaya 
Komponen gaya pada arah $x$ sesuai diagram gaya pada gambar 1dapat dijabarkan sebagai berikut(Astro et al., 2017):

$$
\begin{aligned}
& \sum F_{x}=m a \\
& g\left(\sin \theta-\mu_{k} \cos \theta\right)=a
\end{aligned}
$$

Jika percepatan $a$ adalah $d v / d t$ maka kecepatan ( $v$ ) didapatkan dari hasil intergal persamaan (2) sehingga diperoleh:

$$
v=v_{0}+\left(\sin \theta-\mu_{k} \cos \theta\right) g t
$$

Persamaan (3) dapat didekati dengan regresi linear terhadap grafik kecepatan benda tiap satuan waktu, dengan gradien kemiringan $A$.

$$
\begin{aligned}
& v=A t+B \\
& A=\left(\sin \theta-\mu_{k} \cos \theta\right) g
\end{aligned}
$$

Dengan demikian jika grafik v-t didekati dengan regresi linear, maka persamaan (5) dapat digunakan untuk menentukan koefisien gesek kinetis sebuah benda terhadap permukaan bidang luncuran.

Eksperimen penentuan koefisien gesek kinetis secara konvensional tergolong kompleks seperti banyaknya parameter data yang perlu dikumpulkan dan dianaisis. Pengamatan manual terhadap waktu tempuh benda sepanjang bidang miring juga membutuhkan pengamatan yang cermat dan sulit dilakukan terutama pada panjang lintasan yang relatif kecil (Astro et al., 2017). Berbagai kesulitan eksperimen penentuan koefisen gesek kinetis tersebut mampu diatasi dengan melibatkan teknologi. Dalam fisika untuk membuktikan kebenaran suatu teori dibutuhkanlah eksperimen. Salah satu metode yang digunakan untuk membuktikan masalah ini adalah dengan menggunakan video tracke $r$ (Amirudin et al., 2018). Eksperimen tidak diamati secara langsung melainkan didokumentasikan dalam bentuk video yang selanjutnya dianalisis dengan metode video tracking. Pada eksperimen ini peneliti mencoba menggunakan aplikasi Tracker video analysis dalam eksperimen gaya gesek untuk menentukan koefisien gesek kinetis benda di bidang miring.

Tracker merupakan salah satu aplikasi yang sering digunakan dalam pemodelan fenomena kinematika (Oktriyeni \& Putra, 2019). Tracker adalah sebuah perangkat lunak gratis yang mampu menganalisis dan memodelkan fenomena gerak dan optik yang dikembangkan oleh Open SourcePhysics (Wee \& Lee, 2011). Secara sederhanaTracker memiliki kemampuan untuk melakukan pelacakan pada gerak suatu objek sehingga dapat diperoleh berbagai informasi yang dibutuhkan dalam analisis pada suatu peristiwa gerak. Melalui aktivitas perekaman suatu fenomena gerak yang nyata dengan menggunakan perekam video, maka hasil rekaman tersebut dapat diolah pada aplikasi Tracker.

Tracker video sudah banyak digunakan dalam peenelitian ilmiah yang berfungsi untuk menganalisis suatu hasil rekaman dari suatu percobaan. Pengukuran yang dilakukan pada suatu eksperimen untuk mengetahui keceepatan benda mengggelinding pada bidang miring.

\section{METODE PENELITIAN}

Metode penelitian yang digunakan dalam penelitian ini adalah metode penelitian eksperimen. Metode penelitian eksperimen adalah suatu penelitian yang melibatkan 
manipulasi variabel independen, mengendalikan variabel luar/extraneous serta mengukur efek variabel independen pada variabel dependen (Hastjarjo, 2019). Tujuan dari penelitian eksperimen adalah untuk menetukan hubungan sebab akibat antara dua fenomena (Ratminingsih, 2010).

Eksperimen ini dilaksanakan pada bulan April 2020 bertempat di rumah peneliti, jalan Sam Ratulangi Ende. Alat dan bahan yang digunakan dalam eksperimen ini, yaitu dua buah balok kayu, dengan panjang $\mathrm{m}_{1}=8 \mathrm{~cm}$, lebar $=4 \mathrm{~cm}$, dan tingginya $=5 \mathrm{~cm}$ dan $\mathrm{m}_{2}$ : panjang $=5 \mathrm{~cm}$, lebar $=4 \mathrm{~cm}$ dan tingginya $=3 \mathrm{~cm}$ menggunakan bidang miring dari papan kayu sepanjang $1 \mathrm{~m}$, busur derajat, kamera android dengan resolusi baik, tripot, dan laptop yang telah terinstal aplikasi Tracker.

Eksperimen dilakukan dengan kemiringan bidang $(\theta)$ yang divariasikan sebesar $30^{\circ}$, $28^{\circ}$, dan $26^{\circ}$ dilakukan untuk menentukan koefisien gesek kinetis. Gambar 3 menunjukkan skema analisis video. Prosedur dalam pelaksanaan eksperimen dapat dijelaskan sebagai berikut:

1) Kemiringan bidang diatur sesuai dengan sudut yang dipilih

2) Tempatkan balok dipuncak bidang miring kemudian

3) Lepas balok sehingga dapat meluncur menurun bidang miring

4) Setiap eksperimen direkam menggunakan kamera android dalam format video

5) Analisis pola gerak balok dibidang miring menggunakan Tracker

6) Lakukan regresi linear untuk grafik kecepatan terhadap waktu

7) Substitusi gradien garis kepersamaan (5) untuk mendapat koefisien gesek kinetis.

8) Ulangi prosedur eksperimen ini untuk sudut kemiringan dan benda yang berbeda.

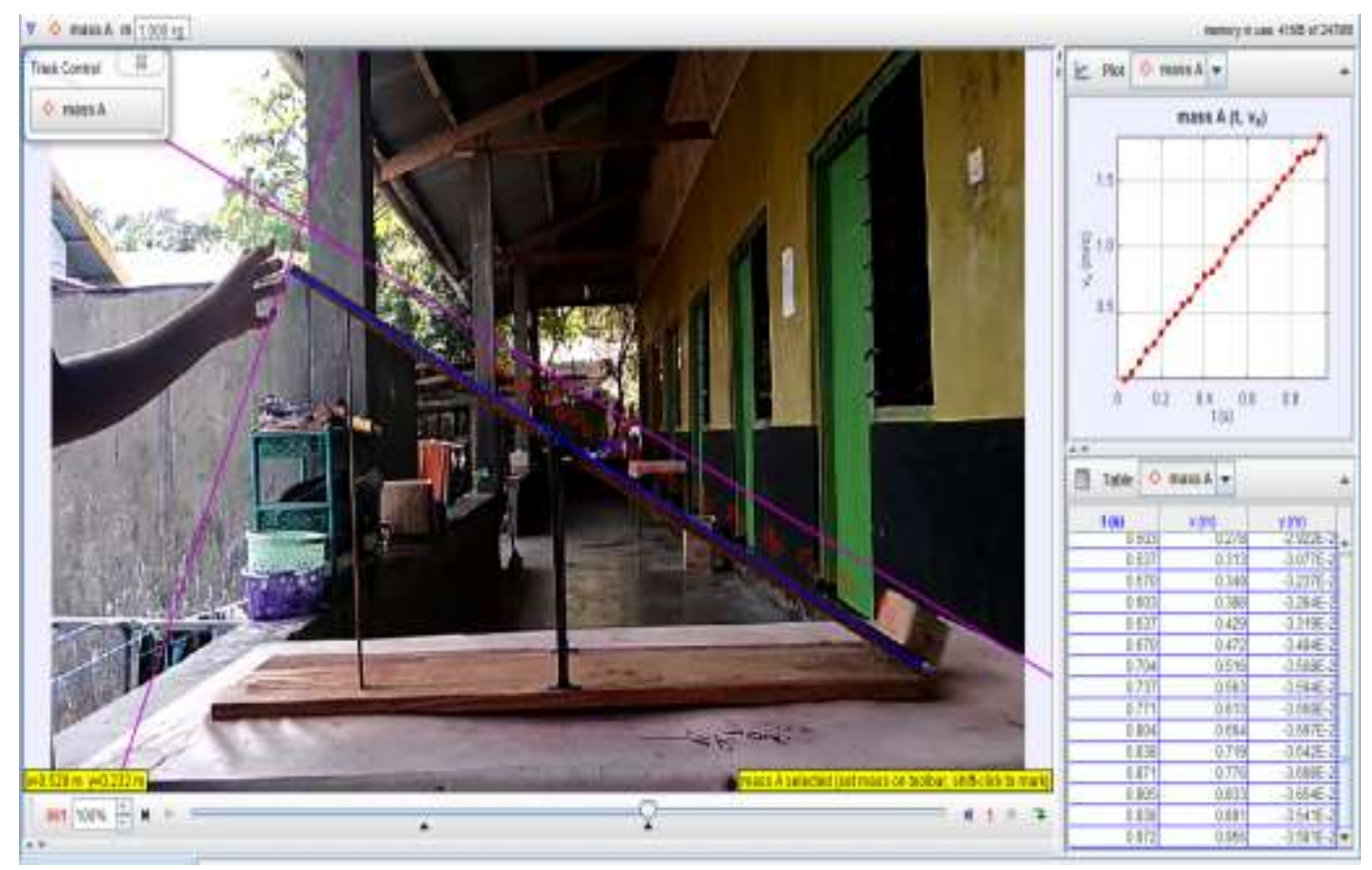

Gambar 2. Skema analisis video menggunakan aplikasi Tracker 


\section{HASIL DAN PEMBAHASAN}

Untuk setiap variasi kemiringan bidang dalam eksperimen penentuan koefisien gesek kinetis benda di bidang miring ini dilakukan secara berulang, dan masing-masing dua data (Intara \& Annas, 2011). Dengan demikian total data yang diperoleh berbentuk berbentuk video yang akan dianalisis menggunakan Tracker. Tahapan analisis data menggunakan Tracker sebagai berikut:

1) Atur sumbu koordinat dengan posisi awal benda sebagai acuan dan arah $x$ sejajar bidang miring, dengan demikian posisi gerak dan kecepatan benda secara otomatis terdata sebagai komponen $x$.

2) Gunakan calibrationstick untuk menetapkan jarak pada frame video sesuai dengan jarak bidang miring yang sudah diukur secara manual.

3) Proses pelacakan posisi balok dikerjakan secara manual dengan cara menentukan poin mass untuk tiap-tiap frame pergerakan balok sejak tepat bergerak hingga mencapai ujung lintasan.

4) Data posisi benda tiap frame secara otomatis diolah dalam bentuk tabel dan grafik kecepatan terhadap waktu.

Contoh hasil analisis regresi terhadap grafik kecepatan terhadap waktu untuk masingmasing balok ditampilkan pada Gambar 4 dan Gambar 5. Garis lurus berwarna merah muda pada gambar merupakan regresi linear terhadap grafik, sedangkan poin-poin berwarna merah adalah titik kecepatan balok pada tiap tiap frame. Nilai gradien garis $A$ sebagai konstanta variabel waktu dan konstanta B secara otomatis ditampilkan pada kolom parameter dan value.

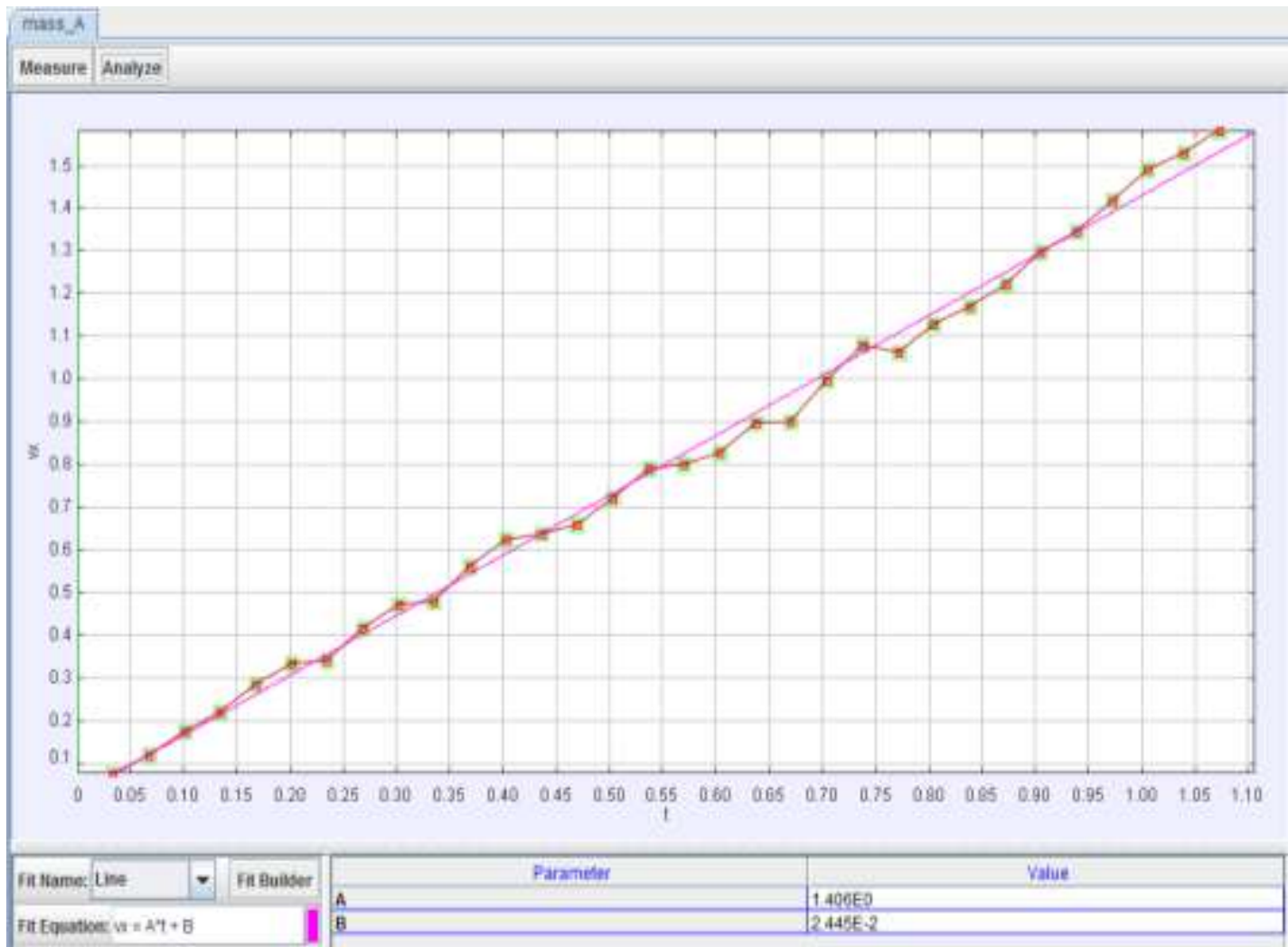

(i) 


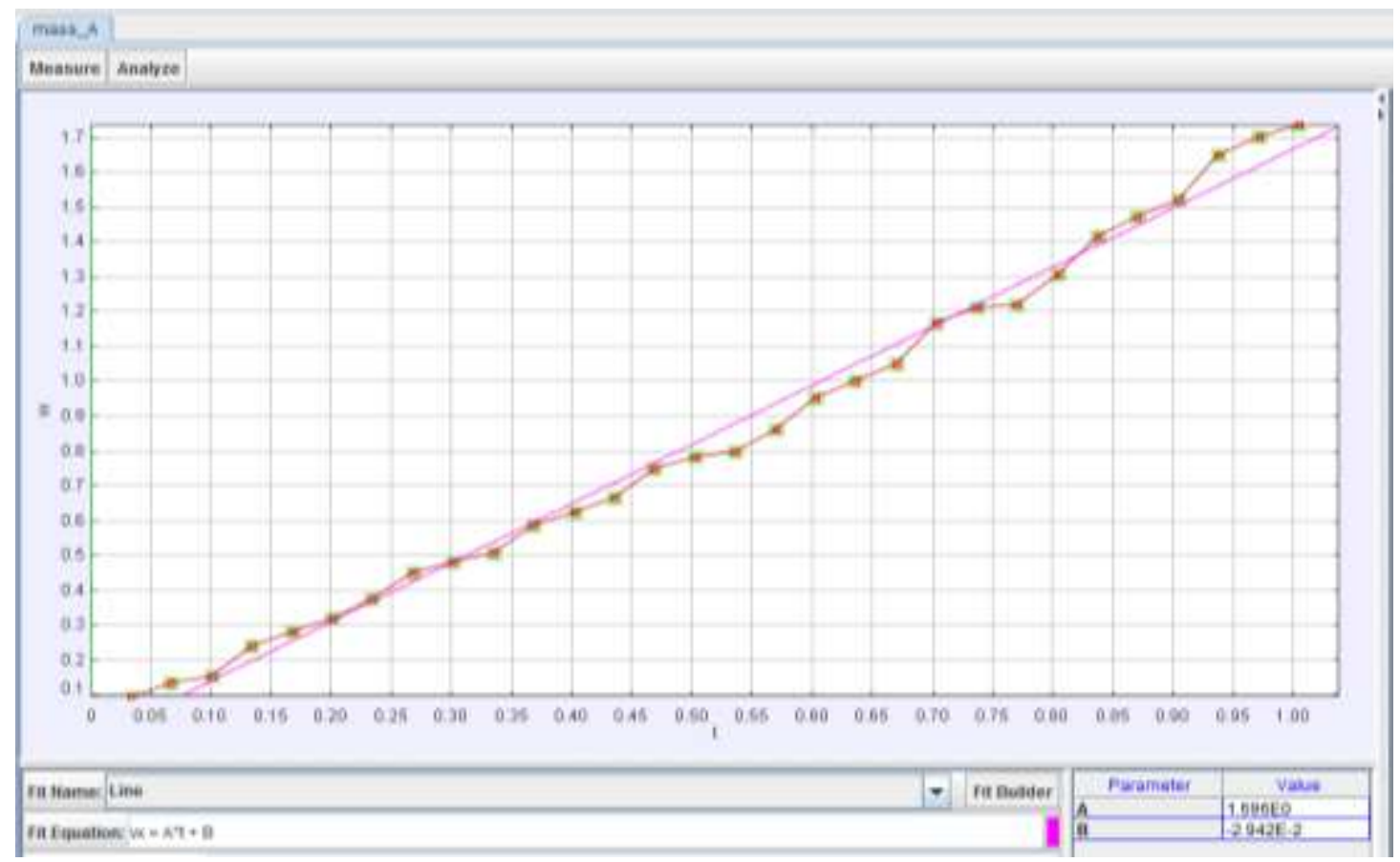

(ii)

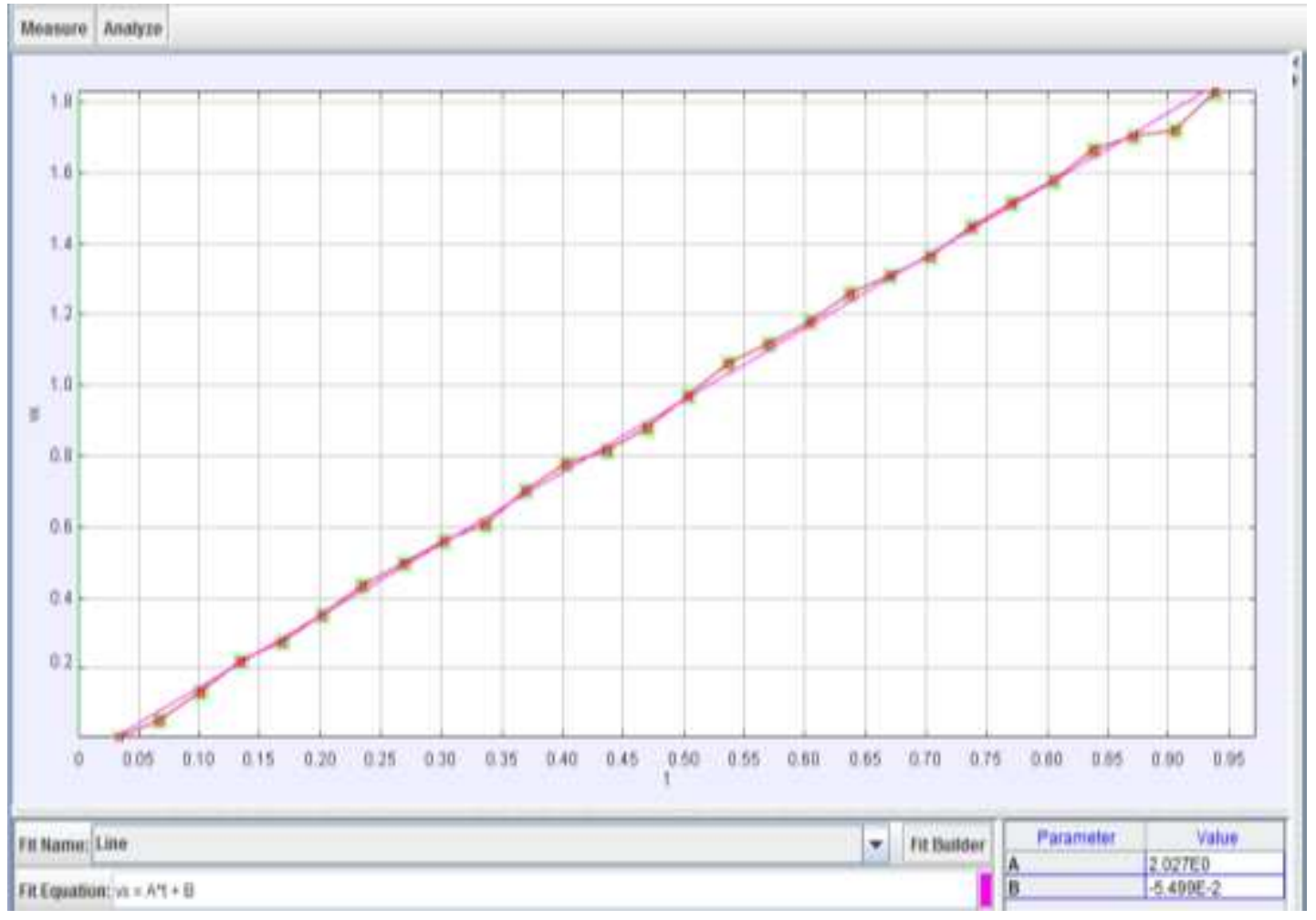

(iii)

Gambar 3. Analisis regresi grafik $v-t$ untuk balok yang berdimensi 8 × 4 × $5 \mathrm{~cm}$ dengan $(\theta)$ : (i) $26^{\circ}$, (ii) $28^{\circ}$, dan (iii) $30^{\circ}$ 


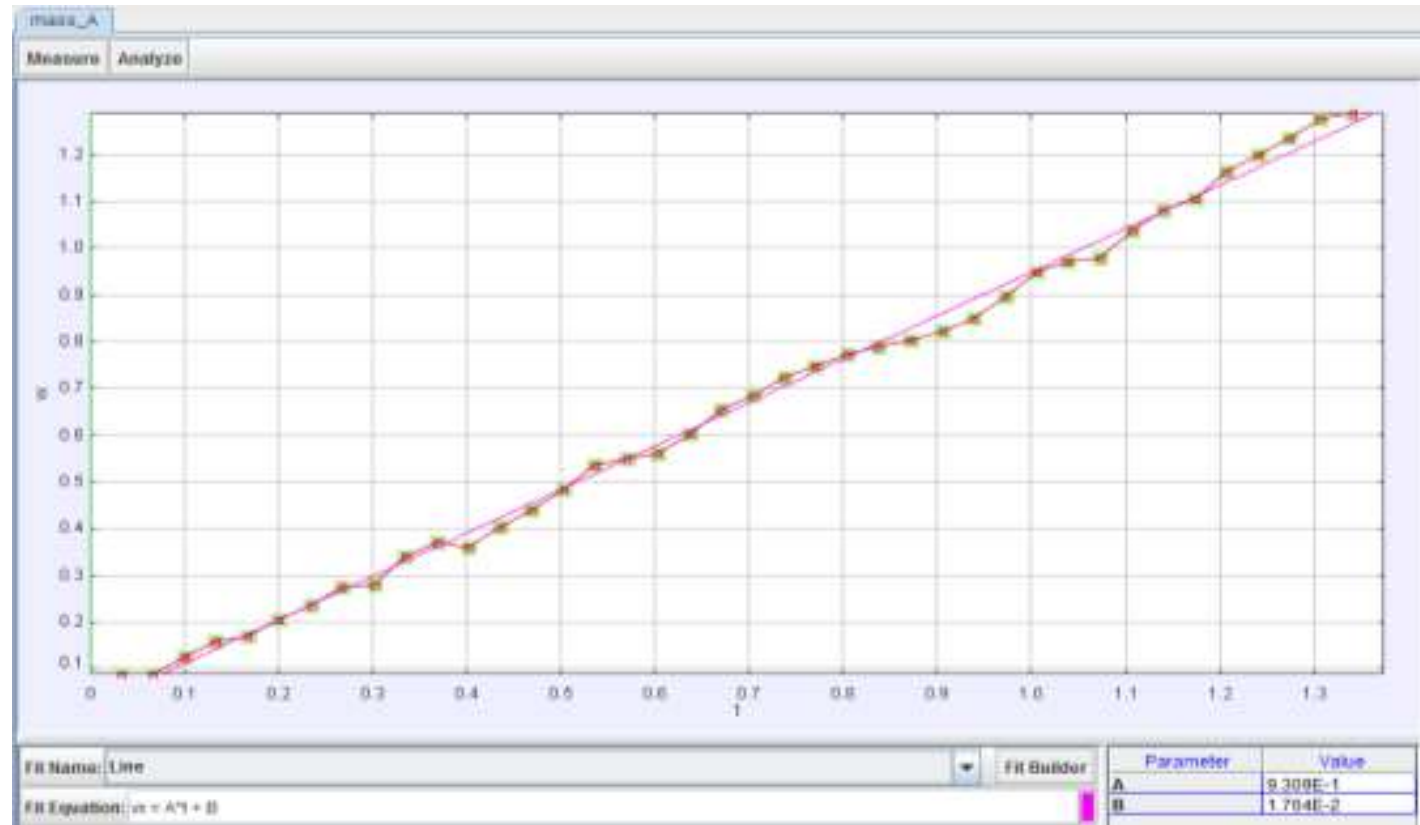

(i)

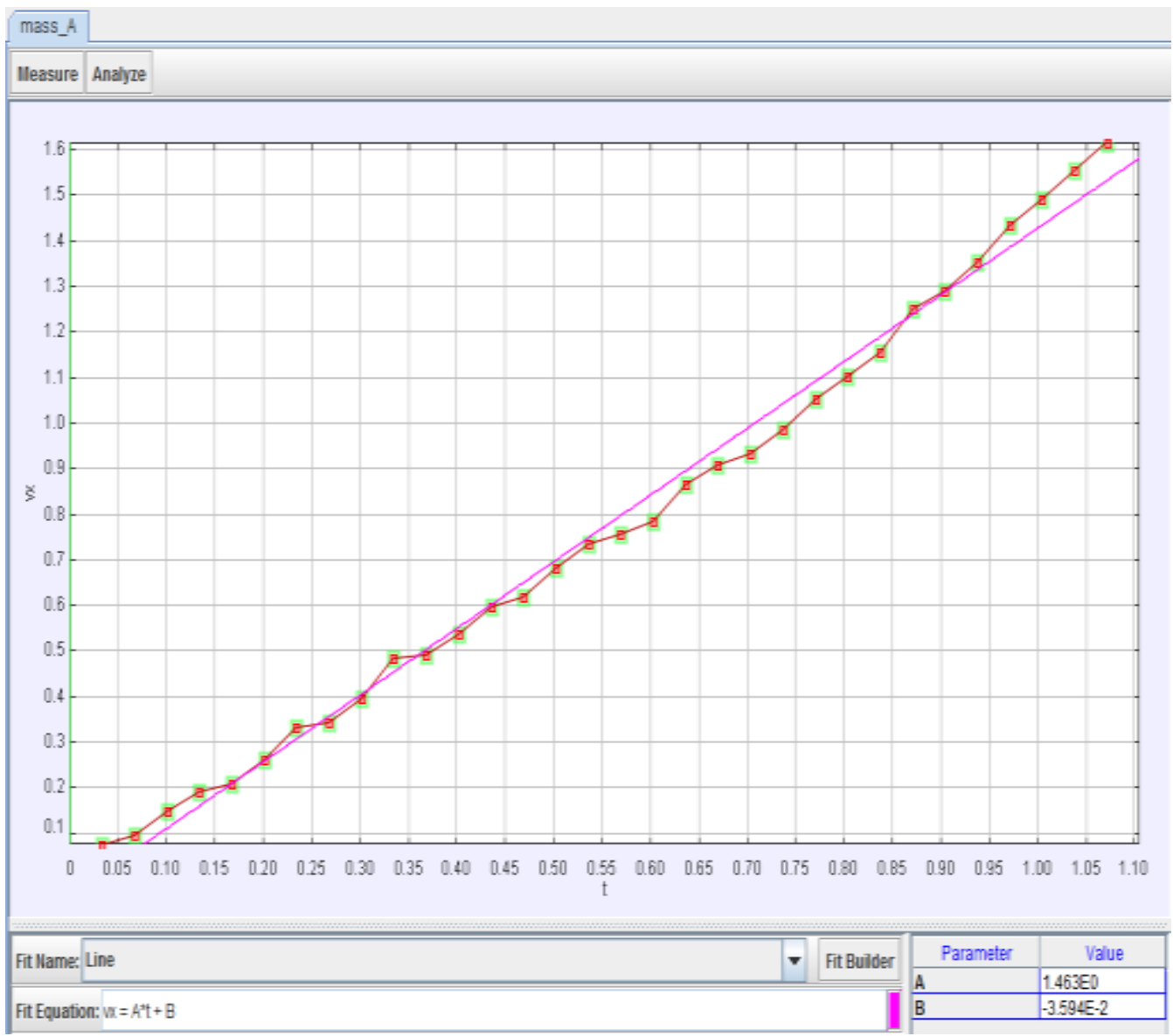

(ii) 


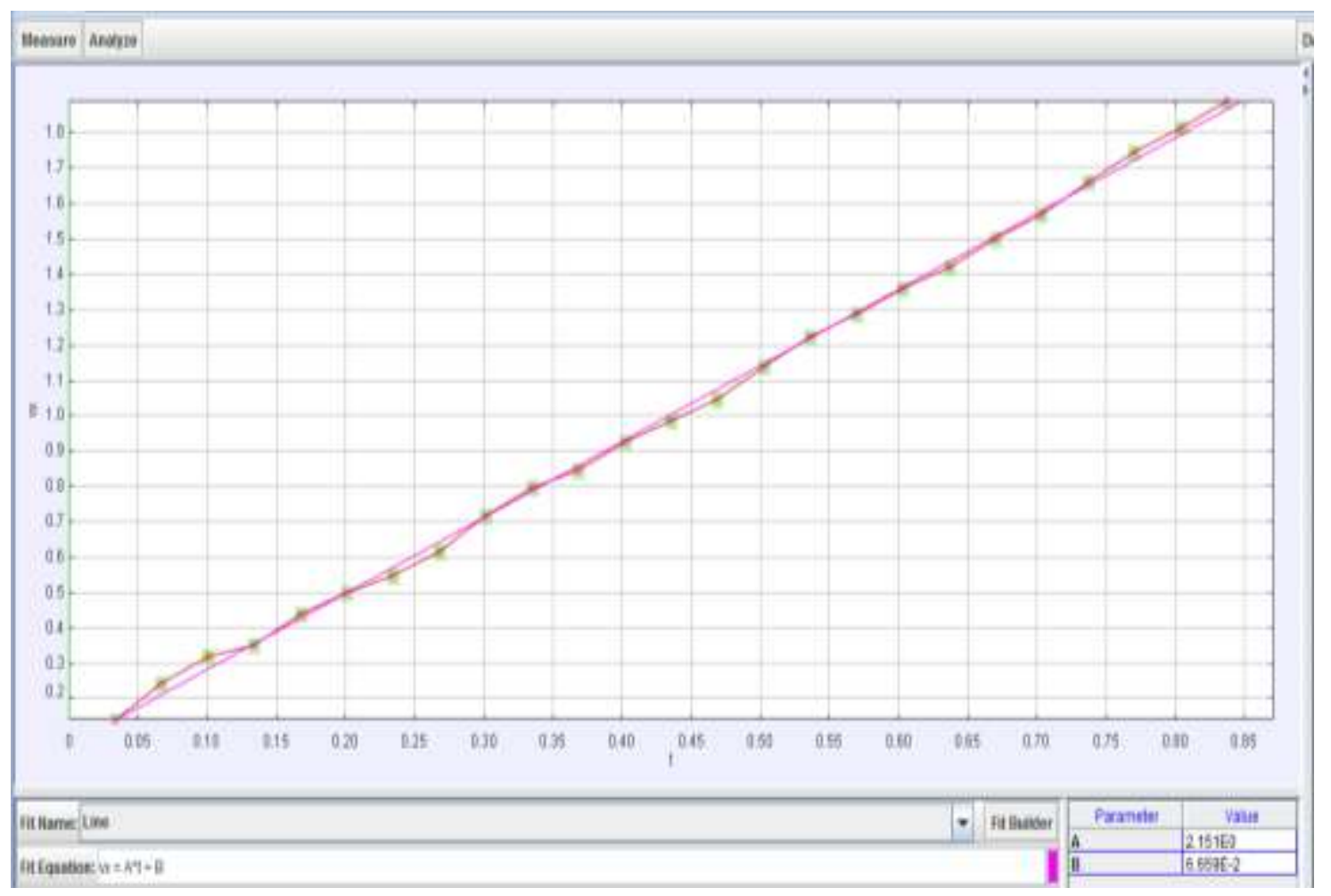

(iii)

Gambar 4. Analisis regresi grafik $v-t$ untuk balok yang berdimensi $5 \times 4 \times 3 \mathrm{~cm}$ dengan $(\theta)$ : (i) $26^{\circ}$, (ii) $28^{\circ}$, dan (iii) $30^{\circ}$

Penentuan koefisien gesek kinetis menggunakan persamaan (5) memerlukan besaranbesaran antara lain sudut kemiringan $(\theta)$, percepatan gravitasi $(g)$, dan gradien garis $(A)$ hasil analisis regresi (Taufik et al., 2018). Eksperimen ini menggunakan nilai percepatan gravitasi sebesar $9,8 \mathrm{~m} / \mathrm{s}^{2}$. Nilai koefisien gesek kinetis antara balok kayu terhadap bidang kayu untuk semua variasi pengukuran dijabarkan pada Tabel 1 dan Tabel 2.

Tabel 1. Koefisien gesek kinetis hasil eksperimen pada balok $m_{1}$

\begin{tabular}{|c|c|c|c|c|c|c|c|}
\hline \multirow{2}{*}{ No } & \multirow{2}{*}{$\theta$} & \multirow{2}{*}{$\operatorname{Cos} \theta$} & \multirow{2}{*}{$\operatorname{Tan} \theta$} & \multirow{2}{*}{$\mathrm{g}\left(\mathrm{m} / \mathrm{s}^{2}\right)$} & \multicolumn{2}{|c|}{ Regresi Linear } & \multirow{2}{*}{$\mu_{k}$} \\
\hline & & & & & $\mathbf{A}$ & B & \\
\hline 1 & $26^{\circ}$ & 0,8988 & 0,4877 & 9,80 & 1,406 & 0,0244 & 0,3281 \\
\hline 2 & $28^{\circ}$ & 0,8829 & 0,5317 & 9,80 & 1,696 & $-0,0294$ & 0,3357 \\
\hline 3 & $30^{\circ}$ & 0,8660 & 0,5774 & 9,80 & 2,027 & $-0,0550$ & 0,3385 \\
\hline
\end{tabular}

Tabel 2. Koefisien gesek kinetis hasil eksperimen pada balok $m_{2}$

\begin{tabular}{cccccccc}
\hline \multirow{2}{*}{ No } & \multirow{2}{*}{$\boldsymbol{\theta}$} & \multirow{2}{*}{$\boldsymbol{C o s} \boldsymbol{\theta}$} & $\operatorname{Tan} \boldsymbol{\theta}$ & $\mathbf{g}\left(\mathbf{m} / \mathbf{s}^{\mathbf{2}}\right)$ & \multicolumn{2}{c}{ Regresi Linear } & \multirow{2}{*}{$\boldsymbol{\mu}_{\boldsymbol{k}}$} \\
& & & & & $\mathbf{A}$ & $\mathbf{B}$ & \\
\hline 1 & 26 & 0,8988 & 0,4877 & 9,80 & 0,931 & 0,0176 & 0,3820 \\
\hline 2 & 28 & 0,8829 & 0,5317 & 9,80 & 1,463 & $-0,0359$ & 0,3626 \\
\hline 3 & 30 & 0,8660 & 0,5774 & 9,80 & 2,151 & 0,0666 & 0,3239 \\
\hline & & & & & $\boldsymbol{\mu}_{\mathbf{k}}$ Rata-rata & $\mathbf{0 , 3 5 6}$ \\
\hline
\end{tabular}


Nilai koefisien gesek kinetis antara balok kayu $\mathrm{m}_{1}$ dan $\mathrm{m}_{2}$ terhadap bidang miring papan kayu menunjukan hasil yang cenderung konsisten berdasarkan analisis data pada Tabel 1 dan Tabel 2. Perbedaan nilai berorde perseratus menunjukkan eksperimen luncuran benda di bidang miring menggunakan video trackerdapat dipakai untuk menentukan koefisien gesek kinetis antara benda dan bidang. Dalam eksperimen ini video tracking digunakan untuk meminimalisir kesalahan pengukuran waktu tempuh balok yang sering digunakan sebagai data primer dalam eksperimen manual.

Namun demikian, beberapa kesalahan masih terdeteksi pada data eksperimen ini sebagaimana yang ditunjukan pada variasi nilai B sebagai konstanta. Secara teori B merupakan kecepatan awal benda yang dalam eksperimen ini seharusnya bernilai nol. Demikian halnya dengan perbedaan koefisien gesek kedua balok berbahan kayu dengan selisih rata-rata 0,022 . Hal ini antara lain disebabkan oleh perbedaan permukaan bidang miring yang tidak dapat dipastikan homogen, faktor lingkungan (temperatur dan kelembapan) yang dianggap ideal, serta penggunaan kamera android dengan framerate per second yang belum memadai.

\section{PENUTUP}

Metode video tracking terbukti memberikan hasil pengukuran yang konsisten sehingga dapat diintegrasikan dalam penentuan koefisien gesek kinetis dan eksperimen kinematika lainnya. Koefisien gesek kinetis antara balok kayu terhadap landasan papan kayu pada eksperimen ini diperoleh nilai rata-rata pada balok $\mathrm{m}_{1}$ sebesar 0,3341 dan balok $\mathrm{m}_{2}$ sebesar 0,3561 .

\section{REFERENS}

Amirudin, D., Astro, R. B., Mufida, D. H., Humairo, S., \& Viridi, S. (2018). Pengaruh Luas Permukaan Benda Terhadap Koefisien Gesek Statis dan Kinetis pada Bidang Miring Dengan Menggunakan Video Tracker. VII, 91-97.

Astro, R. B., Amirudin, D., Mufida, D. H., \& Viridi, S. (2017). Analisis Koefisien Gesek Statis dan Kinetis Benda di Bidang Miring Menggunakan Video Tracker. Prosiding Skf, $265-272$.

Fitrianto, M. B., Darmanto, \& Sysfa'at, I. (2015). Pengujian Koefisien Gesek Permukaan Plat Baja St 37 Pada Bidang Miring Terhadap Viskosotas Pelumas Dan Kekasaran Permukaan (Vol. 11, Issue 1).

Fuadi, Z. (2016). Analisis pengaruh perbedaan koefisien gesekan statis dan kinetis terhadap gerakan stick-slip menggunakan bahan viskoelastis. Jurnal Teknik Mesin Indonesia, 11(1), 51-55.

Hastjarjo, T. D. H. (2019). Rancangan Eksperimen-Kuasi Quasi-Experimental Design. 27(2), 187-203. https://doi.org/10.22146/buletinpsikologi.38619

Hernawati. (2013). Mengetahui koefisien gesek statik dan kinetis melalui konsep gerak melingkar beraturan. Jurnal Teknosains, 7(1), 55-65.

Humairo, S., Astro, R. B., Mufida, D. H., \& Viridi, S. (2015). Analisis koefisien gesek statis 
dan kinetis berbagai pasangan permukaan bahan pada bidang miring menggunakan aplikasi analisis video tracker. October 2019.

Intara, Y. I., \& Annas, M. S. (2011). Pengukuran Gaya Gesek Statis Pada Berbagai Macam Beras. 8(2), 2-9.

Kurniawan, W., \& Handayani, D. E. (2018). Pengembangan Alat Peraga Fisika Pada Materi Gaya Gesek Berbasis Sensor Ultrasonik. Jurnal Ilmu Fisika Dan Pembelajarannya, 2(2), 49-52.

Oktriyeni, \& Putra, A. (2019). Penggunaan Aplikasi Tracker pada Materi Kinematika dan Dampaknya Terhadap Pencapaian Hasil Belajar Siswa Kelas X SMA. Pillar of Physics, 12(1), 89-96.

Ratminingsih, N. M. (2010). Penelitian Eksperimental Dalam Pembelajaran Bahasa Kedua. $6(11)$.

Setyarini, F., \& Natalisanto, A. I. (2016). Analisis Kaitan Koefisien Gesek dan Peluang Pembersihan Pipa Dengan Foam Pig. Seminar Sains Dan Teknologi FMIPA Unmul, $1(1), 18-23$.

Taufik, A., Darmanto, \& Syafa'at, I. (2018). Analisis Keausan Kampas Rem Pada Disc Brake Dengan Variasi Kecepatan. 14(1), 27-32.

Wee, L. K., \& Lee, T. L. (2011). Video Analysis and Modeling Tool for Physics Education: A workshop for Redesigning Pedagogy. 4th Redesigning Pedagogy Conference, July 2012.

Winingsih, P. H., \& Hidayati. (2017). Eksperimen Gaya Gesek Untuk Menguji Nilai Koefisien Gesekan Statis Kayu Pada Kayu Dengan Program Matlab. Jurnal Science Tech, 3(2), 121-126. 